\title{
Angioscopy-guided selective aspiration thrombectomy for acute pulmonary thromboembolism
}

Cardiovascular Center, Osaka Gyoumeikan Hospital, Osaka, Japan

\section{Correspondence to Dr Sei Komatsu,} plaquemap@yahoo.co.jp

Accepted 23 March 2017
Sei Komatsu, Satoru Takahashi, Yasuyuki Toyama, Kazuhisa Kodama

An 83-year-old woman with a history of pulmonary thromboembolism 10 years ago was referred for dyspnea. Anticoagulation therapy was terminated by her family doctor 3 years previously. On admission, D-dimer level was $16.6 \mu \mathrm{g} / \mathrm{mL}$ and arterial blood gas showed $88.1 \%$ on room air. Pulmonary arteriography (PAG) revealed some filling defects, mainly in the right interlobar artery (figure 1A). Non-obstructive angioscopy (NOA) ${ }^{1}$ showed two kinds of thrombi in the pulmonary arteries. At the translucent area, a massive, red, smooth thrombus was seen (figure $1 \mathrm{~B}$, video 1 ). Between the massive thrombus, floating, mobile, white-red, puff-like thrombi were demonstrated (figure 1C, video 2). As the thrombi entered the catheter spontaneously, aspiration was performed using a $20 \mathrm{~mL}$ syringe. Thrombi in the guiding catheter were collected by removing the guiding catheter. For the first trial, red thrombi were effectively aspirated (figure 1D). Puff-like thrombi in the truncus anterior, interlobar artery and basal trunk were aspirated while monitoring via NOA with a total of three trials, and arterial blood gas rapidly improved by $97.9 \%$ on room air. PAG showed diminished deficit, and additional anticoagulation therapy was continued for 3 weeks.
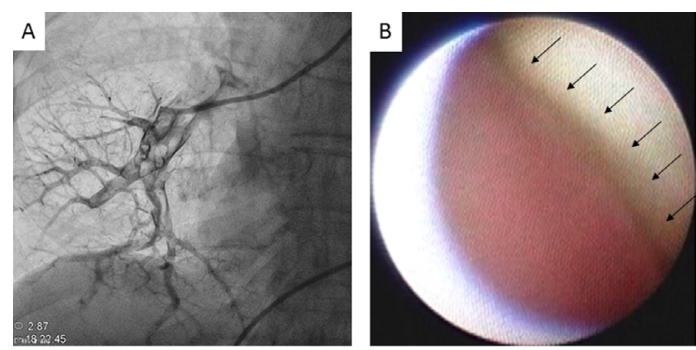

CrossMark

To cite: Komatsu $S$, Takahashi S, Toyama Y, et al. BMJ Case Rep Published Online First: [please include Day Month Year]. doi:10.1136/bcr-2017220059
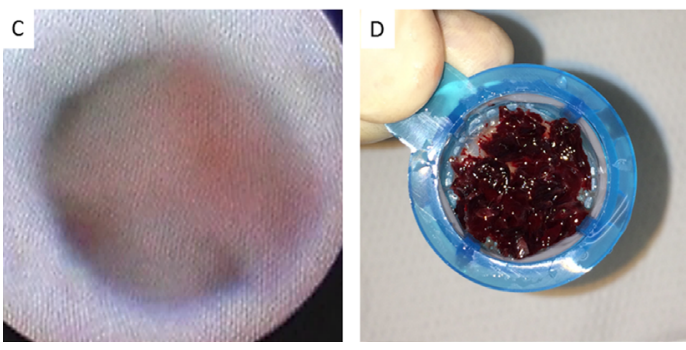

Figure 1 (A) Pulmonary arteriography showed some filling defects in the right interlobar artery. (B) Nonobstructive angioscopy (NOA) showed a massive, red, smooth thrombus (arrows). (C) NOA also showed floating, mobile, white-red, puff-like thrombi between the massive thrombus. (D) Red thrombi were effectively aspirated by the first trial with angioscopy system.

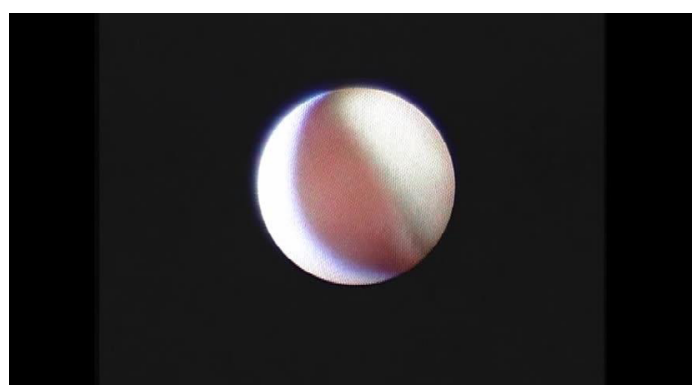

Video 1 Angioscopic video of chronic thrombus.

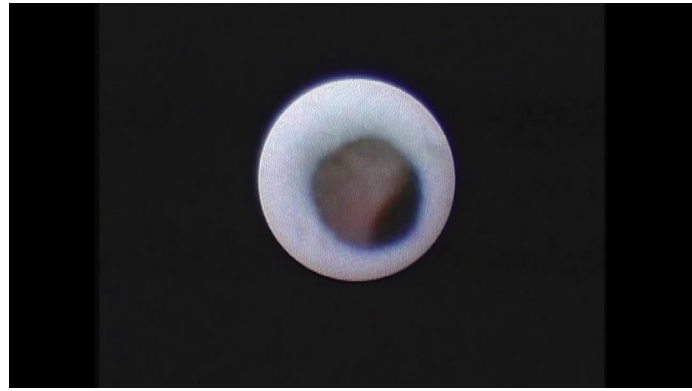

Video 2 Angioscopic video of fresh thrombi.

In the acute phase of pulmonary thromboembolism, selective aspiration thrombectomy was effectively performed by observing the features of the thrombi using NOA. In case of recurrent pulmonary thromboembolism, acute and chronic thrombi may occlude the pulmonary arteries. Acute thrombi may be soft and easier to deform and aspirate compared with chronic thrombi. Chronic thrombi can be difficult to aspirate because they are solid due to organisation.

Learning points

- Acute and chronic thrombi may occlude the pulmonary arteries in patients with recurrent pulmonary thromboembolism.

- Acute thrombi may be soft and easier to aspirate compared with chronic thrombi. Chronic thrombi can be difficult to aspirate because they are solid due to organisation.

- Angioscopy-guided selective aspiration thrombectomy observing the features of the thrombi might be effectively performed in a patient with recurrent pulmonary thromboembolism. 
Contributors KK planned and designed the study. KK, ST and YT conducted the intervention. ST collected the data and images. SK analysed and wrote the first version of the manuscript and the questions. YT performed the supervision of the manuscript, gave expert opinion, looked for the images and corrected the final version. KK supervised all the process, gave expert opinion and gave final approval for the version of the manuscript.

Competing interests KK is the president of Inter-tec Medicals and originally developed non-obstructive angioscopy. SK is a technical consultant for Nemoto Kyorindo. ST and YT declared no conflict of interests.

Patient consent Obtained.
Provenance and peer review Not commissioned; externally peer reviewed.

(C) BMJ Publishing Group Ltd (unless otherwise stated in the text of the article) 2017. All rights reserved. No commercial use is permitted unless otherwise expressly granted.

\section{REFERENCE}

1 Komatsu S, Ohara T, Takahashi S, et al. Early detection of vulnerable atherosclerotic plaque for risk reduction of acute aortic rupture and thromboemboli and atheroemboli using non-obstructive angioscopy. Circ J 2015;79:742-50.

Copyright 2017 BMJ Publishing Group. All rights reserved. For permission to reuse any of this content visit

http://group.bmj.com/group/rights-licensing/permissions.

BMJ Case Report Fellows may re-use this article for personal use and teaching without any further permission.

Become a Fellow of BMJ Case Reports today and you can:

- Submit as many cases as you like

- Enjoy fast sympathetic peer review and rapid publication of accepted articles

- Access all the published articles

- Re-use any of the published material for personal use and teaching without further permission

For information on Institutional Fellowships contact consortiasales@bmjgroup.com

Visit casereports.bmj.com for more articles like this and to become a Fellow 